\begin{tabular}{c}
\hline \hline OPEN \\
JOURNAL \\
SYSTEMS \\
\hline \hline ISSN:2237-2202
\end{tabular}

Available on line at Directory of Open Access Journals

Journal of Hyperspectral Remote Sensing v.7, n.5 (2017) 306-314

www.periodicos.ufpe.br/revistas/jhrs
Journal of

Hyperspectral

Remote Sensing

\title{
Mapping of pedological potential of soils For cultivation of the sugar cane (Saccharum spp) in Paraíba state using geotechnologies
}

\author{
Paulo R. M. Francisco ${ }^{*}$, Djail Santos ${ }^{* *}$, Eduardo R. V. de Lima ${ }^{* * *}$, João M. de Moraes Neto ${ }^{* * * *}$ Homero C. M. da \\ Trindade ${ }^{* * * * *}$
}

\begin{abstract}
"Phd. Research DCR CNPq/Fapesq, Federal University of Paraíba, UFPB. E-mail: paulomegna@ gmail.com;
${ }^{* * *}$ Phd. Prof. Federal University of Paraíba, UFPB. E-mail: santosdj@cca.ufpb.br;

**** Doc. Prof. Federal University of Paraíba, UFPB. E-mail: eduvianalima @ gmail.com;

*** Doc. Prof. Federal University of Campina Grande, UFCG. E-mail: moraes@ deag.ufcg.edu.br;

${ }^{* * * * *}$ Doc. Prof. Federal University of Paraíba, UFPB. E-mail: hcatao@uol.com.br
\end{abstract}

Received 14 November 2017; accepted 20 January 2017

\begin{abstract}
Agricultural planning, as a precept of environmental policy, is an instrument of great importance in the process of managing the rural space and agricultural activity. This work aimed to identify and map the soil information of the lands of the State of Paraíba for the sugar cane cultivation, aiming to recognize the potential of the physical environment. In the methodology, the Agricultural Zoning of the State of Paraíba and the digital map of soils were used in a data base elaborated in the software SPRING 5.2.2, extracted the pedological information of the soils and elaborated the pedological potential. The results showed that with the use of geoprocessing techniques it was possible the spatialization of the areas and the definition of the favorable environments of potential of the culture contributing to the reduction of the risks of degradation of the environment; The State of Paraíba presents a greater pedological potential for the cultivation of sugarcane in $10.04 \%$ of its total area; The areas identified as Very Low Potential correspond to $54.52 \%$ of the total area distributed throughout the State; The Argisols present the smallest and the Neosols the greatest impediments to the development of the culture; It was not possible to map smaller areas due to the scale of work, with the possibility of cultivating the sugar cane cultivation in small areas not identified in this study.

Keywords: Geotechnology, land use capacity, land use restrictions, pedological aptitud.
\end{abstract}

\section{Introduction}

Inadequate land use has caused degradation of soil characteristics by not taking into account its limiting factors, accelerating the impact of human activities on the environment. Economic growth and rational exploitation of the rural environment have been constantly undermined by a lack of more realistic planning based on knowledge of environmental resources and the dynamics of their appropriation (Francisco, 2010). Thus, good rural planning is indispensable for ordering land use, avoiding or minimizing environmental problems, and improving the competitiveness of the agricultural sector (Barros et al., 2012). According to Ballestero et al. (2000), the knowledge of soil characteristics is a fundamental factor for the proper planning of land use, as well as its rational management.

Agricultural planning, as a precept of environmental policy, is an instrument of great importance in the process of managing the rural space and agricultural activity. When properly applied, it rationalizes actions, becoming an instrument for systematizing information, reflecting on problems and speculating potential scenarios for the use of environmental resources (Francisco, 2010).

In planning for the development of sustainable agriculture, knowledge of the environmental vocations of a region to be explored is fundamental. In this sense, prior to any intervention in the rural area, it is essential to have prior knowledge of the potential and limitations of the land. From this knowledge, the agricultural activities can be planned in a way compatible with the support capacity of the same, making possible its use within the conservation principles (Marques et al., 2010).

Currently, surveys of natural resources have been constituted in works of great importance in the direct orientation of the use of a given resource, as well as to subsidize the studies directed to the mapping and environmental management (Francisco, 2010). For FAO (1976), land evaluation is the process of estimating land performance when used for specific purposes, involving the execution and interpretation 
of surveys and studies of relief forms, soils, vegetation, climate, and others aspects. Its objective is to identify and compare the most promising types of land use in terms of applicability to the objectives of the evaluation (Calderano Filho et al., 2007).

According to Sousa et al. (2003), agricultural production is strongly influenced by the edaphoclimatic conditions of the site and has been one of the main limiting factors of production. Depending on availability and soil quality, the productive capacity of the agricultural sector may be even more limiting.

Several states and municipalities have advanced substantially in these studies, especially in the South and Southeast regions, and the areas that are suitable for the exploration of their main cultivation, such as coffee, orange, cotton, wheat, rice and soy are well defined. However, Chagas (1999) warns that the occupation of the Brazilian agricultural space has been carried out without a basic instrument to guide the planning and use of its natural resources.

Sugar cane (Saccharum sp) originates in South Asia, usually grown in tropical and subtropical countries to obtain sugar, alcohol and brandy (Waldheim, 2006). Currently, sugarcane occupies more than 7 million hectares, with Brazil being the largest producer in the world, followed by India, Thailand and Australia (UNICA, 2009).

Sugar cane is cultivated between latitudes of $36^{\circ} \mathrm{N}$ and $31^{\circ} \mathrm{S}$ from sea level up to $1,000 \mathrm{~m}$ altitude. Essentially, it is considered as a tropical plant and has a long vegetative cycle, remaining in the field during all seasons of the year and, therefore, its productivity is strongly influenced by the climate (Varejão-Silva and Barros, 2001).

According to EMBRAPA (2012), in relation to the pedological requirements of the cultivation, the deep soils with texture varying from medium to clayey, well drained are considered more favorable, standing out the Latosols and Argisols in flat relief to smooth wavy. It is also possible to reach satisfactory productivities in Fluvicic Neosols, Fluvic Cambisols, Gleissolos Haplops and Melanic Gleysols when artificially drained. Regarding the nutritional requirements, the plant develops well in soils with $\mathrm{pH}$ in the range of 5.5 to 6.0 , with saturation by bases above $60 \%$ and with adequate supply of $\mathrm{Ca}, \mathrm{N}$ and $\mathrm{K}$. Duarte Jr. and Coelho (2008) indicate that the balance between nitrogen and potassium, associated to calcium, iron, copper and zinc contents in the soil, are the main nutritional limits of productivity, regardless of the method of soil preparation.

According to EMBRAPA (2012), with regard to soil management, the use of conservation practices, such as cultivation rotation, mechanical operations according to ground-level curves, soil maintenance covered by plant residues, especially in stadiums the initial growth of the cultivation, and the traffic of machines under ideal conditions of humidity are fundamental to maintain the organic matter content and the structure of the soil, besides promoting the cycling of nutrients and to avoid the compaction of the soil and its degradation by the process erosive (Ramalho Filho and Beek, 1995; Maia and Ribeiro, 2004; Bezerra and Cantalice, 2006; Rosseto et al., 2008; Portela et al., 2011). In addition, the use of fire should be avoided due to the negative effects of this practice on nutrient cycling and the quality of physical and chemical attributes of the soil (Ceddia et al., 1999; Silva et al., 2007; Rosseto et al., 2008).

According to Francisco et al. (2012), with the advancement of information technology, the provision of satellite images at high resolutions and computer programs for environmental analysis, there has been a great progress in studies related to the management of natural resources. In this context, geoprocessing emerges as a discipline that uses a set of mathematical and computational techniques, in the form of programs, the geographic information system, which enables combinations of information from different technological procedures, generating new information that helps decision making, in different contexts (Duarte and Barbosa, 2009).

Considering the importance of the production of sugar cane and its products for regional and national socioeconomic development, it is necessary to identify the potential of the state soils for its production. Therefore, this work aims to identify and map the soil information of the lands of the State of Paraíba for the sugar cane cultivation, aiming to recognize the potential of the physical environment.

\section{Material and methods}

The study area comprises the State of Paraíba which has an area of $56,372 \mathrm{~km}^{2}$. Its positioning is between the parallels $6^{\circ} 02^{\prime} 12^{\prime \prime}$ and $8^{\circ} 19^{\prime} 18^{\prime \prime} \mathrm{S}$, and between the meridians of $34^{\circ} 45^{\prime} 54^{\prime \prime}$ and $38^{\circ} 45^{\prime} 45^{\prime \prime} \mathrm{W}$ (Francisco, 2010).

The climate is characterized by high average temperatures, varying between 22 and $30^{\circ} \mathrm{C}$, a very small annual thermal amplitude, due to the low latitudes and elevations $(<700 \mathrm{~m})$. Rainfall ranges from 400 to $800 \mathrm{~mm}$ per year, in the semi-arid interior regions, and the wettest coastline may exceed 1,600 mm (Varejão-Silva et al., 1984). According to Francisco et al. (2015), the distribution of rainfall occurs irregularly and with great variation throughout the year and its annual distribution shows the high spatial variability of precipitation in the central sector of the State with lower values around 300 to $500 \mathrm{~mm}$; in the Sertão and Alto Sertão around 700 to $900 \mathrm{~mm}$; in Brejo and Agreste from 700 to $1,200 \mathrm{~mm}$; and on the Coast from 1,200 to $1,600 \mathrm{~mm}$ (Figure 1). 


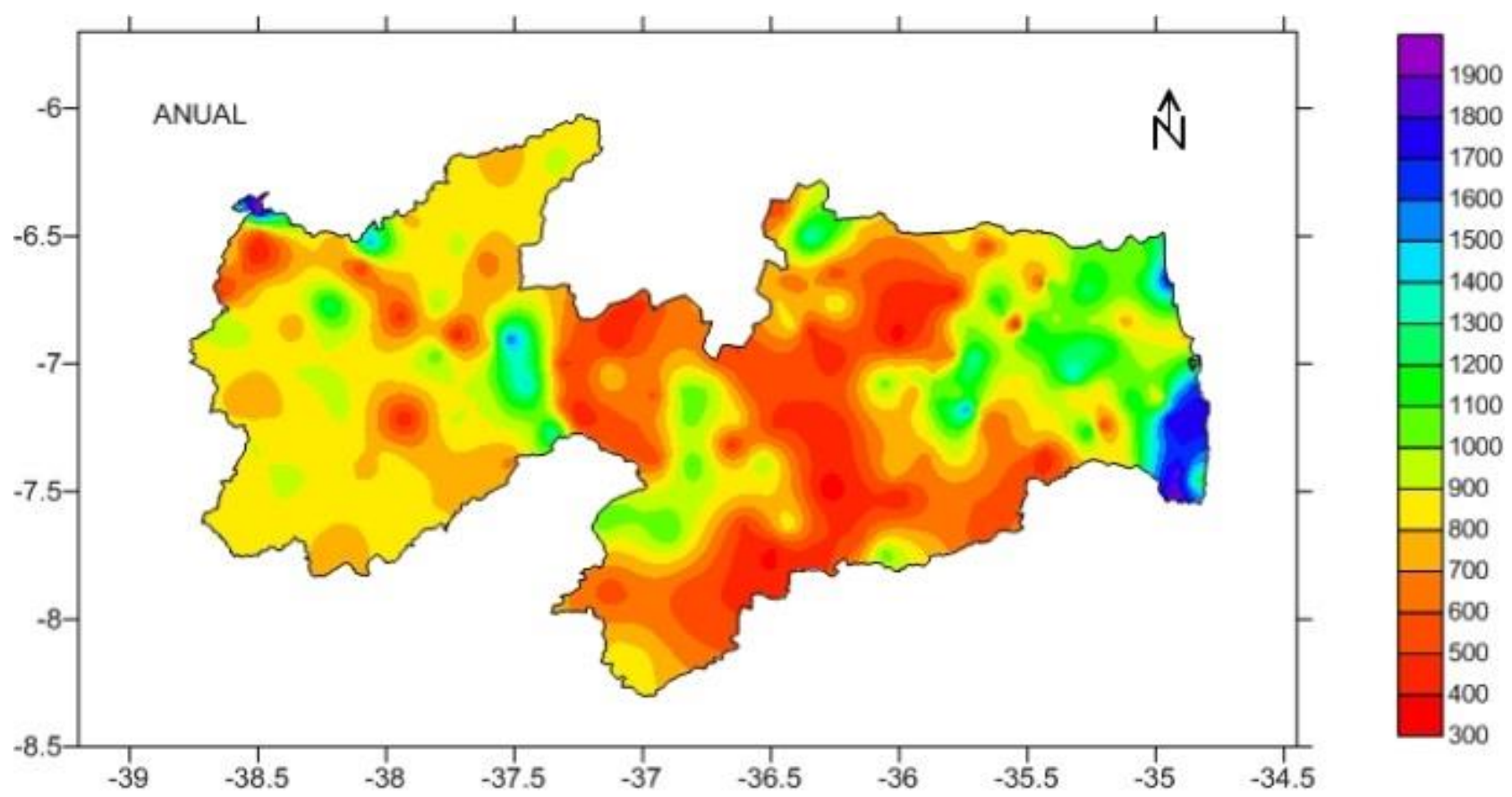

Figure 1 - Average annual rainfall (mm) for the last 102 years. Source: Francisco et al. (2015).

The relief is generally very diversified, constituting different relief forms worked by different processes, acting under different climates and on differentiated rocks (Figure 2). Regarding geomorphology, there are two groups formed by the most significant climatic types: humid, subhumid and semiarid. The present use and vegetation cover are characterized by forest formations defined as open shrub caatinga, closed arboreal shrub caatinga, closed arboreal caatinga, coastal board, mangroves, rainforest, semi-deciduous forest, Atlantic forest and restinga (PARAÍBA, 2006).

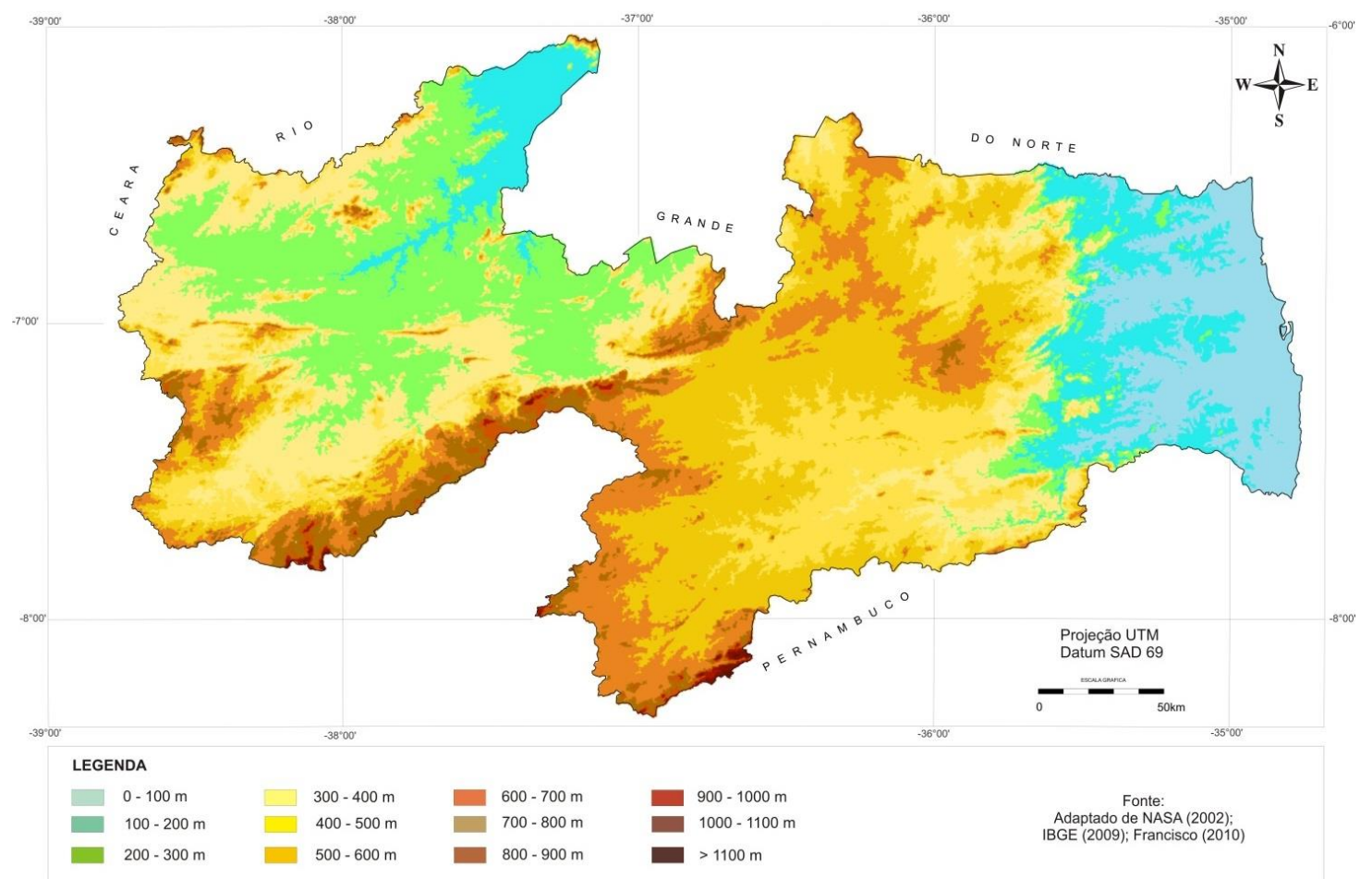

Figure 2 - Hypsometric map of the state of Paraíba. Font: Francisco et al. (2014). 
The predominant classes of soils in the study area (Figure 3) are described in the Agricultural Zoning of the State of Paraíba (PARAÍBA, 1978), and these differ for the geological, pedological and geomorphological diversity, also attending to a diversity of soil characteristics, related to morphology, color, texture, structure, slope and stoniness, among other characteristics as Francisco (2010) observes.

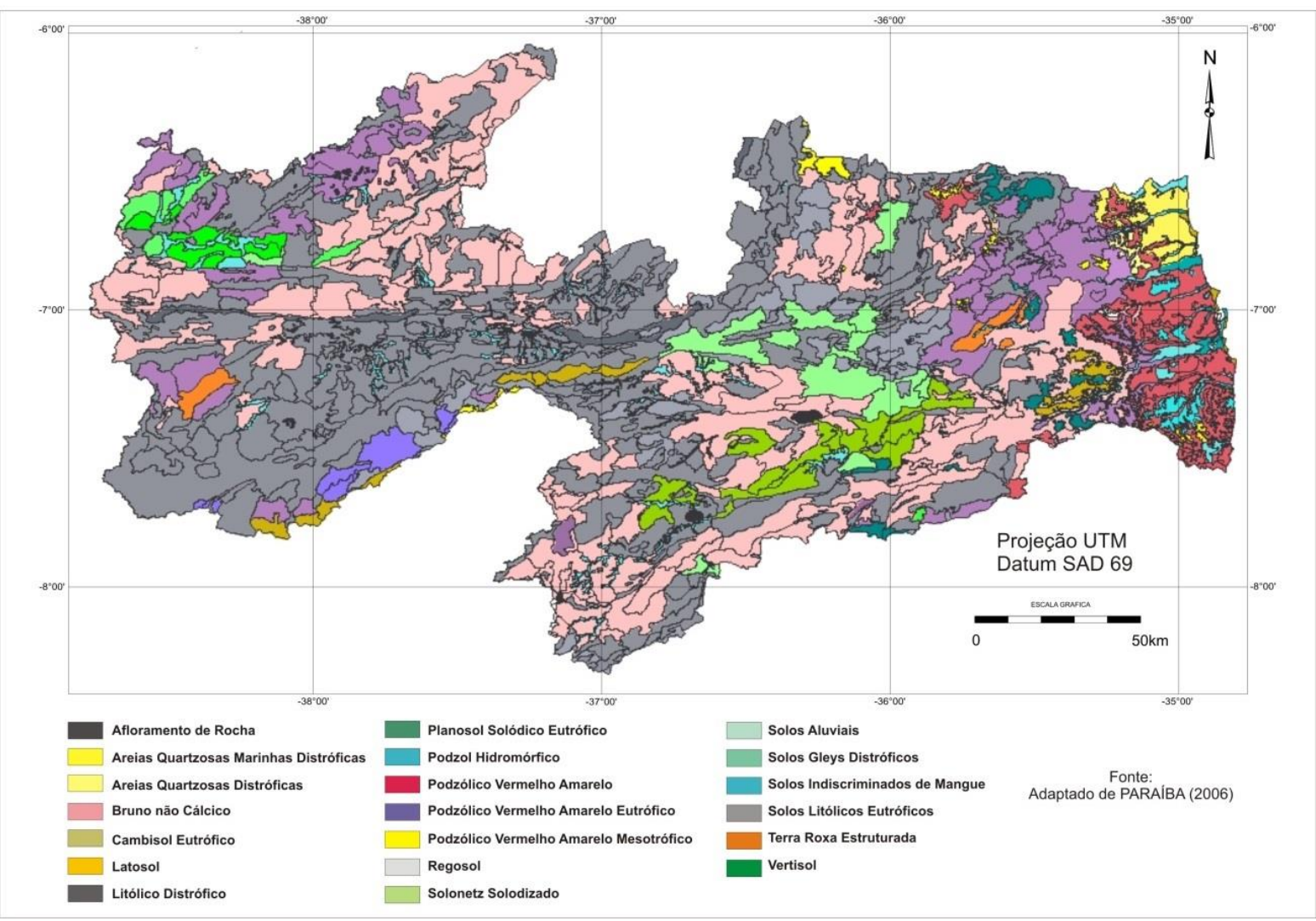

Figure 3 - Soils of the State of Paraíba. Source: Francisco et al. (2013).

From the interpretation of the pedological data the classes of capacity of use of the soils of Paraíba presented in Figure 4, were determined according to the criteria originally proposed by Lepsch et al. (1991), adapted in the form of an interpretive key of the attributes of the land, which are described in the Agricultural Zoning of the State of Paraíba (PARAÍBA, 1978). By this classification the alternatives of use are limited by the degree and nature of the restrictions, imposed by one or more attributes of the land, taking into account also the possibility of land improvements, by the adoption of conservation practices, which include, besides the control practices erosion, the complementary ones of soil improvement.

In this work, to elaborate the map of the pedological potential, it was used as cartographic base, the archives elaborated by Francisco et al. (2014), processed in software SPRING 5.2.2 in the UTM/SAD69 projection, which contains the digital map of soils of the State Water Resources Plan
(PARAÍBA, 2006), updated in its limits according to IBGE (2009).

For the representation of the land use class map, the interpretation made in the Agricultural Zoning of the State of Paraíba (PARAÍBA, 1978) was assigned to the classes of capacity of use, the colors of the legend according to the manual of Lepsch et al. (1996).

In the establishment of the pedological potential applied to the zoning of the sugar cane cultivation (PARAIBA, 1978), the lands were classified according to the degree of adaptability to the development of the cultivation, for a level of management developed. The latter shall be admitted to the more or less intensive application of capital and a reasonable level of specialized technical knowledge for the improvement of soil and cultivation conditions, which include motorized traction and correction and fertilization techniques recommended by agricultural research. 


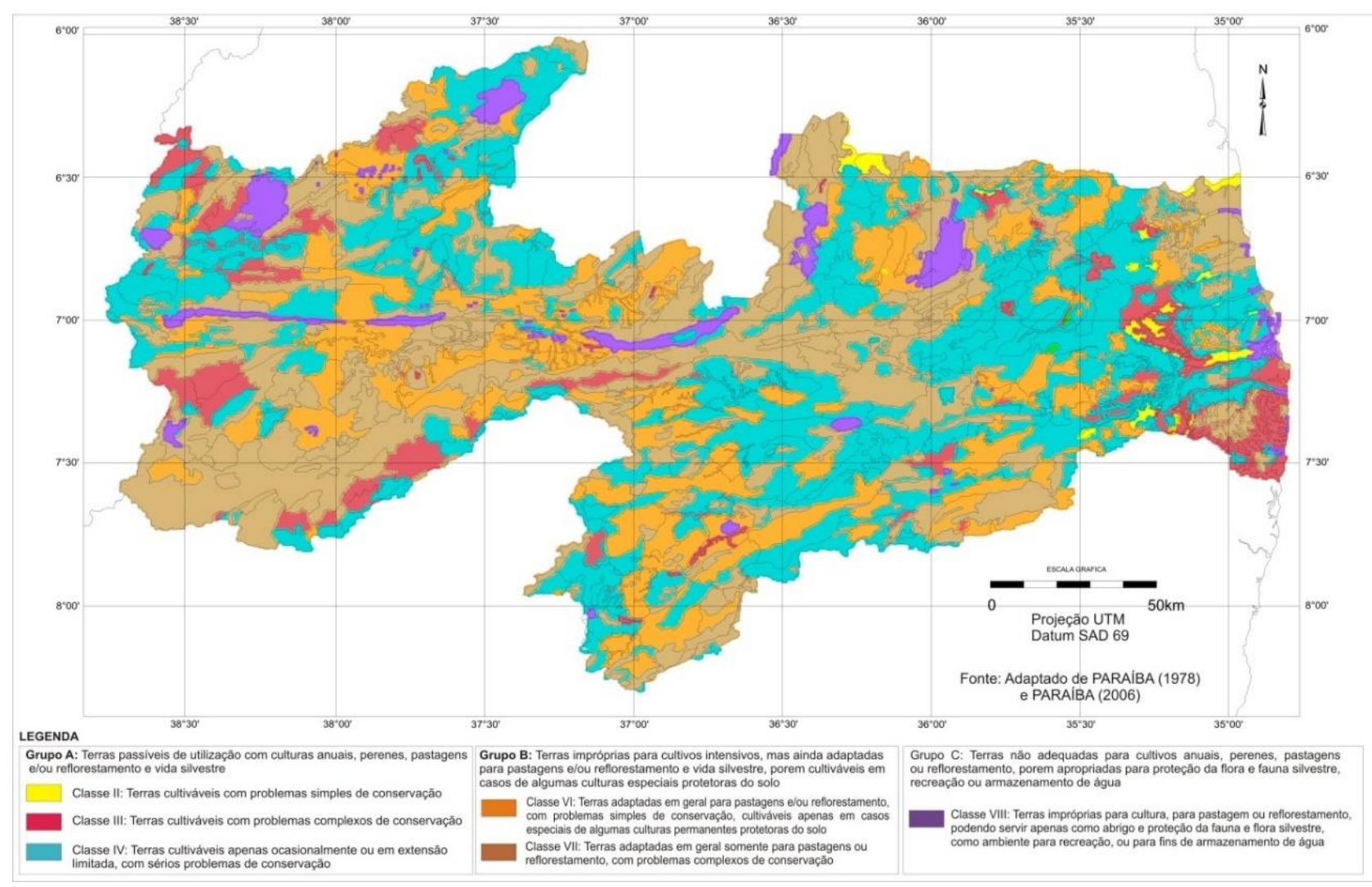

Figure 4 - Class of land use capacity of the State of Paraíba. Source: Francisco et al. (2013).

In the interpretation for the sugar cane cultivation, the lands were grouped into Aptitude Classes, subdivided into Categories, seeking to represent jointly the potentialities of the associations of soils, components of each of the mapping units.

Thus, we have described:

- Category 1 (Full Aptitude): areas with classes and/or associations of use capacity classes, which are appropriate for the cultivation with slight limitations of use, imposed by the soil characteristics, topography and erosion. Correspond to the Use Capacity classes of categories A and B of the potential of the Lands. From category A: II2 to II7, III1 to III15. Of category B: II8, III16 and III18.

- Category 1a (Full Aptitude): areas with associations of land use classes with cultivation dominance, which have slight limitations of use, imposed by soil characteristics, topography and erosion. They correspond to all classes of capacity Use of categories $\mathrm{C}$ and $\mathrm{C} 1$ potential of Land. From category C1: II9, III19, III20, III22, III25 to III28. From category C: III30, III32 to III42.

- Category 1b (Full Aptitude): areas with classes and/or combinations of capacity classes of use represented by alluvial soils, suitable for cultivation with moderate problems and/or drainage complexes. Correspond to the Usage Capacity classes of categories $\mathrm{E}$ of the potential of the Lands. Of category E: II1, III10, III21, III31, and III105.
- Category 2 (Moderate Aptitude): areas with use capacity classes with moderate limitations for use with the cultivation, due to fertility characteristics and/or topography. They correspond to the Class of Use Capacity of category D1 of the potential of the Lands. From category D1: IV1 to IV5, IV9 and IV10.

- Category 2a (Moderate Aptitude): areas with usability of class associations Category 2. Refers to use capacity classes of category D1 potential of Lands. From category D1: IV6, IV7, IV11 to IV21.

- Category 2b (Moderate Aptitude): areas with classes of capacity of use with strong limitations for use with the cultivation due to drainage characteristics and associations of land classes unfit for cultivation. They correspond to the Class of D2 Use Capacity of Land potential. From category D2: IV85, IV86, IV89 to IV104.

- Category 2c (Moderate Aptitude): areas with severely restricted use capacity classes for use with the cultivation due to imperfect drainage characteristics and associations of land classes unfit for cultivation. They correspond to the Class of Use Capacity of the category $\mathrm{F}$ of the potential of the Lands. From category F: III17, III24, III29, IV22 to IV80.

- Category 3 (Restricted Aptitude): areas with classes of capacity of use with strong limitations for use with the cultivation due to the characteristics of low soil fertility and/or excessive drainage. They correspond to the Classes of Use Capacity of the D2, 
F and G1 categories of potential oh the Lands. From category D2: IV81 to IV84. From category F: IV8. From category G1: VI9.

- Category 3 (Restricted Aptitude): areas with classes of capacity of use with strong limitations for use with the cultivation due to the characteristics of low soil fertility and/or excessive drainage. They correspond to the Classes of Use Capacity of the D2, $\mathrm{F}$ and G1 categories of potential oh the Lands. From category D2: IV81 to IV84. From category F: IV8. From category G1: VI9.

As a final form of presentation, the map of the potential for sugar cane culture was re-elaborated, following the class standardization proposed by EMBRAPA (2012). In this proposal, adopted in similar work for the State of Alagoas, the above fitness classes were regrouped into five classes, according to the following correspondence: Pedological Potential Very High $=$ Class 1 (Full Aptitude); High = Class 1a and 1b (Full Aptitude); Medium $=$ Class 2, 2a, 2b and 2c (Moderate Aptitude); Low $=$ Class 3 (Restricted Aptitude); Very Low $=$ Class I (Inapt).

\section{Results and discussion}

According to the map of pedological Potential for sugar cane cultivation (Figure 5), no lands with very high potential were identified. The edaphic characteristics indicate that these lands constitute areas with classes and/ or associations of classes of use capacity that are appropriate for the cultivation with slight limitations of use, imposed by the characteristics of the soils, topography and erosion.

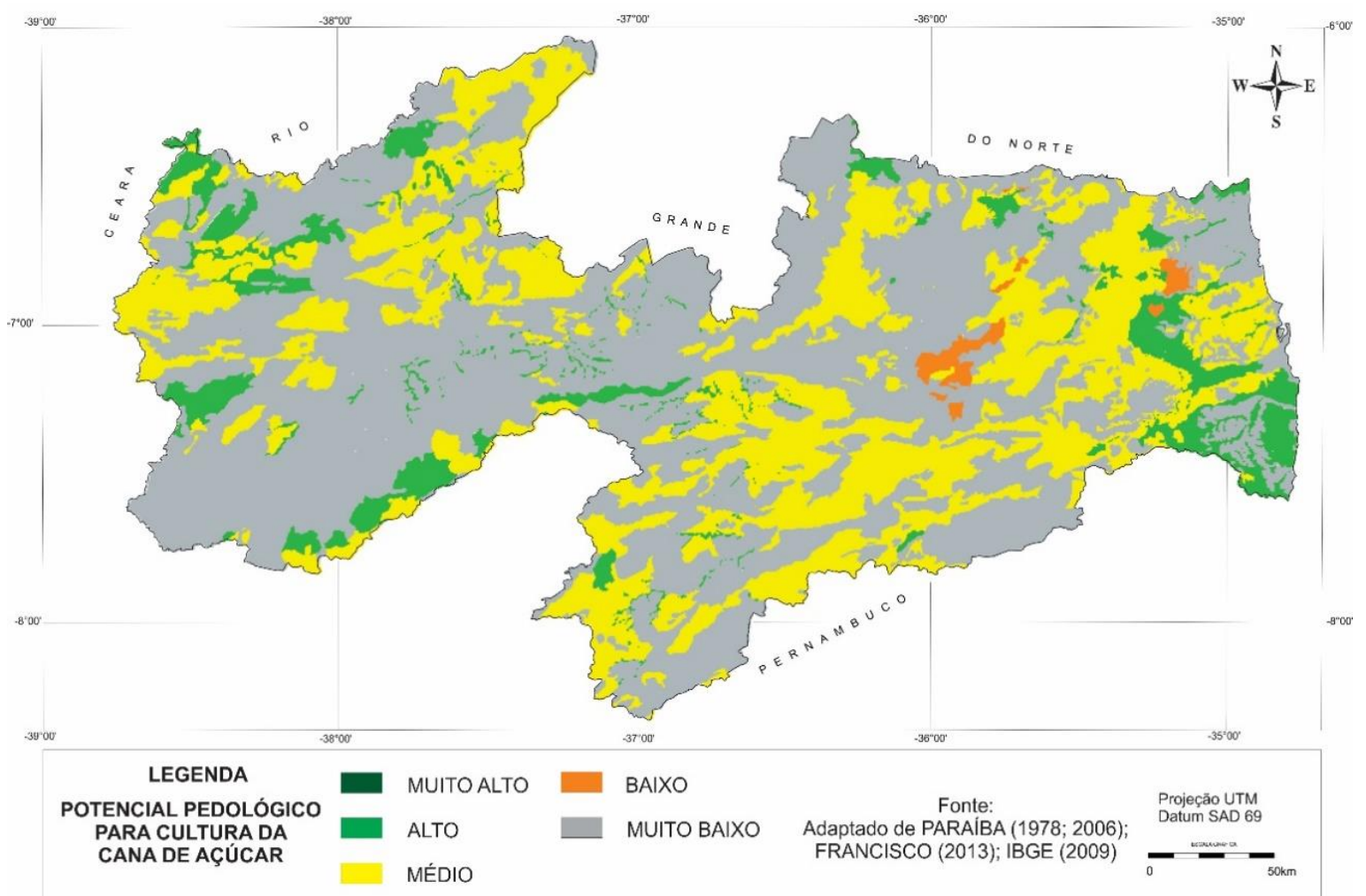

Figure 5. Pedological potential for sugarcane cultivation in the State of Paraíba.

According to EMBRAPA (2012), this is due to the low natural fertility of soils in the humid zone, which are generally acidic and dystrophic, some of which have an aluminum character, which impairs plant growth. On the other hand, in the drier environments, in this case the Sertão, there are problems related to the small effective depth, stoniness, rochness, salinity, sodicity, among others.
According to the map of Pedological Potential for the culture of the sugar cane cultivation (Figure 5), $5,661.87 \mathrm{~km}^{2}$ of high potentials were identified, representing $10.04 \%$ (Table 2) of the total area of the State, distributed in Agreste Acatingado, Brejo, Mata and Litoral, Alto Sertão Alto and Baixo Sertão do Piranhas and Cariris de Princesa.

Table 2. Distribution of the classes of the pedological potential of the sugar cane cultivation

\begin{tabular}{|c|c|c|c|c|c|c|c|c|c|c|c|}
\hline \multicolumn{12}{|c|}{ Classes of Pedological Potential } \\
\hline Ver & iigh & $\mathbf{H i}$ & & Medi & & Lc & & Very & & & \\
\hline $\mathbf{k m}^{\mathbf{2}}$ & $\%$ & $\mathbf{k m}^{2}$ & $\%$ & $\mathbf{k m}^{2}$ & $\%$ & $\mathbf{k m}^{2}$ & $\%$ & $\mathbf{k m}^{2}$ & $\%$ & $\mathbf{k m}^{2}$ & $\%$ \\
\hline 0,00 & 0,00 & $5.661,87$ & 10,04 & $19.448,72$ & 34,50 & 523,04 & 0,93 & $30.736,00$ & 54,52 & 56372 & 100,00 \\
\hline
\end{tabular}


The edaphic characteristics indicate that these lands constitute areas with classes and/or associations of classes of use capacity represented by Alluvial soils, appropriate for the cultivation. These areas are of the occurrence of the Eutrophic Yellow Red Argisol, where the degrees of limitations can be considered light, and the conditions found for the exploration of these lands can be considered satisfactory for the sugar cane cultivation.

According to Jacomine et al. (1975), sugarcane cultivation in terms of large cultivation is concentrated in the coastal wetlands of the Northeast, Ceará Mirim Valley, Rio Grande do Norte, Recôncavo Baiano, and in the Brejo Paraibano. As a small cultivation, sugar cane is cultivated in wetlands and small valleys with Alluvial soils. On the coast of the States of Paraíba and Rio Grande do Norte, the culture is installed in the valleys of the low rivers that cut the region like Ceará Mirim, Trairi, Jacu, Mamanguape, Paraíba and others of smaller size. The homogeneous microregions covered by the sugarcane cultivation, in terms of great farming, are the Paraibano and Brejo Paraibano Litoral.

It's noted that this distribution occurs extreme standards due to the occurrence of the weather to be very small, and when adverse events occur in the areas referenced characteristics change according to the recorded rainfall or occurred for the reviewed period. The region of Cariri/Curimataú is what's presented in the critical range of rainfall for dry quarter. Are observed isolated points with anomalous rainfall in the areas of Alto Sertão, Sertão, Agreste, Brejo and Litoral.

EMBRAPA (2012) observed a ratio of $39 \%$ in the state of Alagoas area and distributed in Argisols or Latosols with natural fertility ranging from medium to low and generally plane and undulated relief. These results are similar to those found in this study.

The areas with average potential, observed in this work, totaled $19,448.72 \mathrm{~km}^{2}$, representing $34.5 \%$ of the total surface area and are distributed throughout the State. Soil characteristics indicate that these lands constitute areas with use capacity classes with moderate limitations for use with the cultivation due to the fertility characteristics and/or topography, and/or areas with severely restricted use capacity classes for use with the cultivation due to imperfect drainage characteristics and associations of land classes unfit for cultivation. Most of these areas are occurring soils mostly type Luvisol Chromic typical Orthic and Luvisol hypochromic typical Orthic in the regions of Cariri/Curimataú in Sertão the Cambisol Tb typical eutrophic, while type Alfissol Eutrophic soils occur in the Agreste region and on the Coast, Yellow Argissol Dystrophic fragipic.

The Low Potential areas, observed in this study, represent a total of $523.04 \mathrm{~km}^{2}$, representing
$0.93 \%$ of the total area of the State, located in the region of Cariri, Agreste and Brejo. In these areas, there are soils with strong impediments to the agricultural use of the sugar cane cultivation. These lands constitute areas with capacity classes of use with strong limitations for use with the cultivation due to the characteristics of low soil fertility and/or excessive drainage.

These occur in areas of Plinthosol Argilúvico Eutrophic espessarênico in Agreste and caatinga Coastal, region in the Brejo region in Argisol RedYellow Dystrophic abruptic, in the region of the Sertão, in Neosol Quartzarênico fragipanico, Haplic Cambisol Tb, Eutrophic Latossol and Luvissol Crômico Typical Orthotic.

The areas with very low potential make up a total of $30,740.37 \mathrm{~km}^{2}$ of land, corresponding to $54.53 \%$ of the total area distributed throughout the state. These areas are unsuitable for exploitation with the cultivation, being represented by classes of capacity of use or associations of classes whose characteristics of soils and/or topography present severe restrictions for use. These areas occur on the coastline in Spodosol Ferrocarbic typical Orthic in Dystrophic Ultisol fragipânico abrúptico and Entisol Solodic; in the Sertão and Borborema regions, in the Neolithic Regolítico eutrofico léptico and, in its majority, in the Neossol Litholic Eutrophic typic.

EMBRAPA (2012) observed that about 59\% of the State of Alagoas, presented low and very low potential for sugarcane and occur in the coastal region.

According to PARAÍBA (1978), although it occupies a very small area, the sugar cane culture has a diffusion higher than the areas classified as potentially apt. Considering the pedologically suitable and restricted areas, there is theoretically scope for an extension of the cultivated area.

However, this cultivation does not have a great possibility of expansion when one considers the need for high productivity mainly through agricultural mechanization, in order to achieve economic profitability, which would of course reduce the usable areas. Francisco (2010), working with the classification and mapping of lands for the agricultural mechanization of Paraíba, observed similar results in relation to the probability of expansion of mechanization in the State, and found that the main impediments are shallow soils (effective depth) and stoniness.

For this work, it's observed that the Argisols present the smallest impediments, because they are classified in the High Potential in its majority and in the Average Potential, in smaller proportion. The Argisols form the 2nd most extensive order of Brazilian soils, covering eutrophic, dystrophic, allelic and even soils, shallow to very deep, abrupt or not, 
with gravel, gravel or not, with fragipã and even with solodic character, which generalized appreciation for soils of this order as a whole (Oliveira, 2005).

Rational agricultural practices such as fertilization, conservation measures and irrigation considerably increase productivity in the areas of Argisols and the use of agricultural machinery is strongly limited in the areas of strong undulating relief (Cavalcante et al., 2005).

It's observed that the maps of this work, in the scale of 1:200,000, give an overview of the environments where the lands have more or less adequacy to the planting and development of the culture of the sugar cane. According to EMBRAPA (2012), however, this is an evaluation performed independent of climatic conditions and, therefore, does not offer, in isolation, all the necessary elements for sustained exploitation of the cultivation.

\section{Conclusions}

With the use of geoprocessing techniques, it was possible to spatialize the areas and define the favorable potential environments of the sugar cane cultivation, contributing to reduce the risk of environmental degradation.

The soils of the State of Paraíba present a High Potential for the cultivation of the sugar cane culture in $10.04 \%$ of its area, distributed in the Agreste Acatingado, Brejo, Mata and Litoral, Alto Sertão Alto and Baixo Sertão do Piranhas and Cariris de Princesa.

Areas with a medium potential amount to $34.5 \%$ of the total area and are distributed throughout the state.

The areas with low potential, observed in this study represent $0.93 \%$ of the total area of the State, located in the region of Cariri, Agreste and Brejo.

The Very Low Potential areas make up $54.53 \%$ of the total area distributed throughout the State.

For this work, it's observed that the Argisols present the smallest impediments, because they are classified in the High Potential in the majority, and in the Average potential, in a smaller proportion.

It was not possible to map smaller areas due to the scale of work, with the possibility of cultivating the sugar cane cultivation in small areas that were not identified in this study.

\section{Acknowledgements}

the first author.

CNPq/FAPESQ by granting research grant to

\section{References}

Ballestero, S.D., Lorandi, R., Tremocoldi, W.A., 2000. Mapeamento pedológico semidetalhado da área de relevante interesse ecológico de Pedra Branca (Tremembé, SP). Revista Biociência 6, 7 15.

Barros, A.H.C., Varejão-Silva, M.A., Tabosa, J.N., 2012. Aptidão climática do Estado de Alagoas para culturas agrícolas. Relatório Técnico. Convênios SEAGRI-AL/Embrapa Solos n.10200.04/0126-6 e 10200.09/0134-5. Embrapa Solos, Recife.

Bezerra, S.A., Cantalice, J.R.B., 2006. Erosão entre sulcos em diferentes condições de cobertura do solo, sob cultivo da cana-de-açúcar. Revista Brasileira de Ciência do Solo 30, 565-573.

Calderano Filho, B., Guerra, A.J.T., Palmieri, F., Argento, M.S.F., Correia, J.R., Ramalho Filho, A., 2007. Aptidão agroecológica de terras: proposta de avaliação em paisagens rurais montanhosas ocupadas por pequenos agricultores na serra do mar. Cadernos de Ciência \& Tecnologia 24, 39-75.

Cavalcante, F.deS., Dantas, J.S., Santos, D., Campos, M.C.C., 2005. Considerações sobre a utilização dos principais solos no estado da Paraíba. Revista Científica Eletrônica de Agronomia 4, 1-10.

Ceddia, M.B., Anjos, L.H.C., Lima, E., Ravelli Neto, A., Silva, L.A., 1999. Sistemas de colheita da cana-de-açúcar e alterações nas propriedades físicas de um solo Podzólico Amarelo no estado do Espírito Santo. Pesquisa Agropecuária Brasileira 34, 1467-1473.

Chagas, C.daS., $1999 . \quad$ Zoneamento Agropedoclimático do Brasil. Disponível: www.cnps.embrapa.br/search/pesqs/proj02/proj02. html\#11. Acesso: 20 jul. 2016.

Duarte Jr., J.B., Coelho, F.C., 2008. A cana-de-açúcar em sistema de plantio direto comparado ao sistema convencional com e sem adubação. Revista Brasileira de Engenharia Agrícola e Ambiental 12, 576-583.

Duarte, S.M.A., Barbosa, M.P., 2009. Estudo dos recursos naturais $\mathrm{e}$ as potencialidades no semiárido, estado da Paraíba. Revista Brasileira de Engenharia Ambiental 6, 168-189.

EMBRAPA. Empresa Brasileira de Pesquisa Agropecuária, 2012. Zoneamento Agroecológico do Estado de Alagoas. Potencial Pedológico do Estado de Alagoas para Culturas Agrícolas. Relatório Técnico. Convênios SEAGRIAL/Embrapa Solos N.os 10200.04/0126-6 e 10200.09/0134-5. Embrapa Solos, Recife. Disponível:

http://ainfo.cnptia.embrapa.br/digital/bitstream/ite m/77202/1/Relatorio-Pot-Pedologico.pdf. Acesso: 1 nov. 2014.

FAO. Food and Agriculture Organization of the United Nations, 1976. A Framework for Land Evaluation. FAO, Rome. (Soils Bulletin, 3). 
Francisco, P.R.M., 2010. Classificação e mapeamento das terras para mecanização do Estado da Paraíba utilizando sistemas de informações geográficas. Dissertação (Mestrado). Areia, UFPB.

Francisco, P.R.M., Chaves, I.deB., Lima, E.R.V.de., 2013. Classificação de terras para mecanização agrícola e sua aplicação para o Estado da Paraíba. Revista Educação Agrícola Superior 28, 30-35.

Francisco, P.R.M., Chaves, I.deB., Lima, E.R.V.de., 2012. Mapeamento das Terras para Mecanização Agrícola - Estado da Paraíba. Revista Brasileira de Geografia Física 5, 233-249.

Francisco, P.R.M., Chaves, I.deB., Lima, E.R.V.de, Santos, D., 2014. Tecnologia da geoinformação aplicada no mapeamento das terras à mecanização agrícola. Revista Educação Agrícola Superior 29, 45-51.

Francisco; P.R.M., Mello, V.daS., Bandeira, M.M., Macedo, F.L.de, Santos, D., 2016. Discriminação de cenários pluviométricos do Estado da Paraíba utilizando distribuição Gama incompleta e teste Kolmogorov-Smirnov. Revista Brasileira de Geografia Física 9, 1206-1216.

IBGE. Instituto Brasileiro de Geografia e Estatística, 2009. Disponível: http://www.ibge.gov.br. Acesso: 12 mar. 2011.

Jacomine, P.K.T., Ribeiro, M.R., Burgos, N., 1975. Aptidão agrícola dos solos da região nordeste. Serviço nacional de levantamento e conservação de solos, região nordeste. Embrapa, Recife. (Boletim Técnico, 42).

Lepsch, I.F., Bellinazzi Jr., R., Bertolini, D., Espíndola, C.R., 1996. Manual para levantamento utilitário do meio físico e classificação de terras no sistema de capacidade de uso. 4.a Aprox. SBCS, Campinas.

Maia, J.L.T., Ribeiro, M.R., 2004. Propriedades de um Argissolo Amarelo fragipânico de Alagoas sob o cultivo contínuo de cana-de-açúcar. Pesquisa Agropecuária Brasileira 39, 79-87.

Marques, F.A., Araújo Filho, J.C.de, Barros, A.H.C., Lopes, E.H.B., Barbosa, G.M.N., 2010. Aptidão pedoclimática das culturas dos feijões caupi e comum para o estado de Alagoas. Congresso Brasileiro de Ciência do Solo, Uberlândia.

Oliveira, J.B., 2005. Pedologia Aplicada. FEALQ, Piracicaba.

PARAÍBA. Governo do Estado - Secretaria de Agricultura e Abastecimento - CEPA - PB, 1978. Zoneamento Agropecuário do Estado da Paraíba. Relatório ZAP-B-D-2146/1. UFPB-Eletro Consult
Ltda.

PARAÍBA. Secretaria de Estado da Ciência e Tecnologia e do Meio Ambiente, 2006. Agência Executiva de Gestão de Águas do Estado da Paraíba, AESA. PERH-PB: Plano Estadual de Recursos Hídricos: Resumo Executivo \& Atlas. Brasília.

Portela, J.C., Cogo, N.P., Amaral, A.J.do, Gilles, L., Bagatini, T., Chagas, J.P., Portz, G.Â., 2011. Hidrogramas e sedimentogramas associados à erosão hídrica em solo cultivado com diferentes sequências culturais, com diferentes condições físicas na superfície. Revista Brasileira de Ciência do Solo 35, 225-240.

Ramalho Filho, A., Beek, K.J., 1995. Sistema de Avaliação da Aptidão Agrícola das Terras. 3 ed. rev. Embrapa-CNPS, Rio de Janeiro.

Rosseto, R., Dias, F.L.F., Vitti, A.C., Cantarella, H., Landell, M.G.A., 2008. Manejo conservacionista e reciclagem de nutrientes em cana-de-açúcar tendo em vista a colheita mecânica. Informações Agronômicas 124, 8-13.

Silva, A.J.N., Ribeiro, M.R., Carvalho, F.G., Silva, V.N., Silva, L.E.S.F., 2007. Impact of sugarcane cultivation on soil carbon fractions, consistence limits and aggregate stability of a Yellow Latosol in Northeast Brazil. Soil Tillage Research 94, 420424.

Sousa, R.F.de, Cordão Sobrinho, F.P., Beltrão, N.E.deM., Feitosa, P.H.C., Araújo, A.E.de, Motta, J.D., Gonzaga, E.daN., 2003. Aptidão pedoclimática da cultura do algodão herbáceo na área do assentamento Campo Comprido I Patos, PB. Congresso Brasileiro de Algodão, Goiânia.

UNICA. Dados e cotações: estatísticas. Disponível: http://www.unica.com.br/dadosCotacao/estatistica/ . Acesso: 10 abr. 2009.

Varejão-Silva, M.A., Barros, A.H.C., 2001. Zoneamento de aptidão climática do Estado de Pernambuco para três distintos cenários pluviométricos. Relatório Técnico. COTEC/DATA AGROS/SPRRA-PE, Recife.

Varejão-Silva, M.A., Braga, C.C., Aguiar, M.J.N., Nietzsche, M.H., Silva, B.B., 1984. Atlas climatológico do Estado da Paraíba. FINEP/DCACCT-UFPB/EMBRAPA, Campina Grande.

Waldheim, P.V., Carvalho, V.S.B., Correa, E., França, J.R.A., 2006. Zoneamento Climático da Cana-deAçúcar, da Laranja e do Algodão Herbáceo para a Região Nordeste do Brasil. Anuário do Instituto de Geociências 29, 30-43. 